\title{
Gairdner award winner recognized for sharing his techniques
}

— Cite as: CMAJ 2017 November 13;189:E1402. doi: 10.1503/cmaj.109-5518

Posted on cmajnews.com on Oct. 24, 2017.

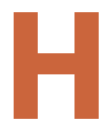

is protein visualization tools have impressed his colleagues, but it was Lewis Kay's decision to share his methods with the scientific community that earned him the 2017 Canada Gairdner International Award.

"He's always been very, very good at sharing these techniques with other scientists in Canada and abroad," said Gary Shaw, Canada Research Chair in Structural Neurobiology at Western University.

Kay is a professor in the departments of chemistry, biochemistry and molecular genetics at the University of Toronto. He is also a senior scientist at The Hospital for Sick Children. He is perhaps best known for his contribution to the development of nuclear magnetic resonance (NMR) spectroscopy, a technique used to study the dynamics and structure of molecules, such as proteins. NMR spectroscopy has many applications, and some researchers believe it has great potential in the area of personalized medicine to help develop targeted drugs.

Whatever the application, Kay is pleased that his work is helping other scientists in their research. "Seeing people take ideas and move them in directions in ways that you couldn't have imagined, and on systems whose importance is unequivocal, is a great thing for me," said Kay.

In Shaw's lab at Western, the techniques pioneered by Kay are used frequently. "We use these experiments, I'm not going to say on a daily basis but, definitely every week," he said. "They've sort of become bread-and-butter experiments that we need in order to study protein structure and protein interactions." Shaw's work focuses on the function and mutation of proteins, such as Parkin,

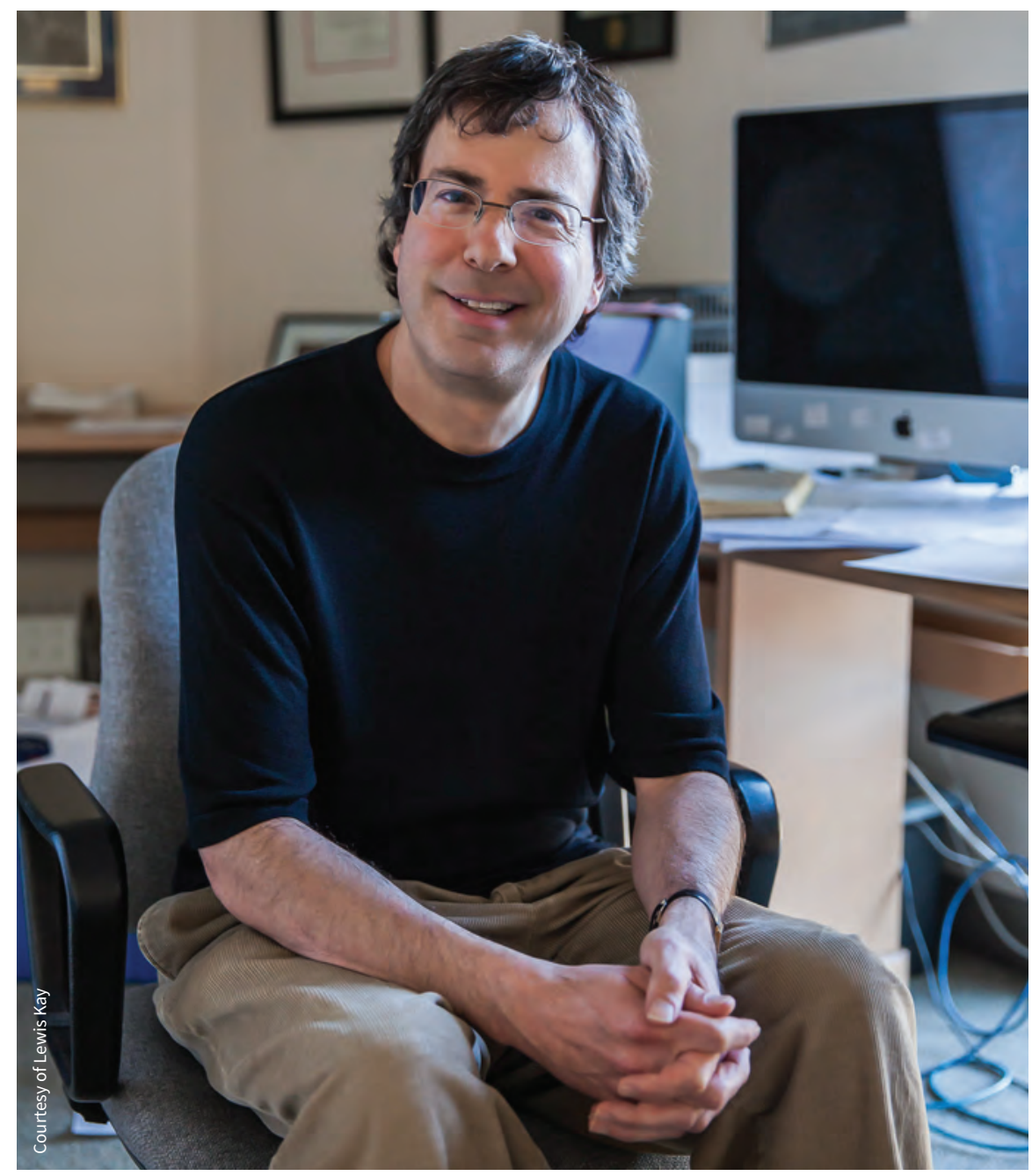

Gairdner award winner Lewis Kay helped develop nuclear magnetic resonance spectroscopy.

which is mutated in some forms of Parkinson disease.

Though many of the potential applications of his work lay in the future, Kay is using the recognition he is receiving now to raise awareness about the importance of supporting research in Canada.

"The funding system is not able to support all of the outstanding research that is being done in the country," he said. "I think that we could be doing a much better job and I think what Canada has shown, time and time again, is that the talent levels are high - the talent is there, but you have to nurture that talent."

\section{Caroline O'Neil, CMAJ intern}

